\title{
Cicatrização: conceitos atuais e recursos auxiliares - Parte I*
}

\section{Cicatrization: current concepts and auxiliary resources - Part $I^{*}$}

\author{
Samuel Henrique Mandelbaum ${ }^{1} \quad$ Érico Pampado Di Santis ${ }^{2} \quad$ Maria Helena Sant'Ana Mandelbaum ${ }^{3}$
}

\begin{abstract}
Resumo: - O estudo da cicatrização da pele envolve uma enorme gama de eventos e de situaçóes espe ciais. Exige conhecimentos básicos de anatomia, histologia, bioquímica, imunologia, farmacologia, entre outras ciências. $\mathrm{O}$ artigo faz revisão dos conceitos de cicatrização, em seus diversos aspectos, e ressalta a importância da atuação multidisciplinar na abordagem das feridas, bem como a percepção do paciente como um todo. São abordados os aspectos econômicos que representam as feridas agudas e crônicas. Apresenta ainda os recursos que podem auxiliar o processo de cicatrização, bem como os diversos tipos de curativos disponíveis.
\end{abstract}

Palavras-chave: Cicatrização de feridas; mecanismos defensivos e curativos.

Summary: The study of cicatrization of the skin involves an enormous gamut of events and special situations. It requires a basic knowledge of anatomy, bistology, biochemistry, immunology, pharmacology and many other sciences. This article offers a revision of the concepts of cicatrization, in its diverse aspects, and underscores the importance of a team with practitioners from various fields for the wound management as well as a global perception of the patient. The economic aspects of acute and chronic wounds are considered. Furthermore, the resources which can be used to aid the bealing process and the various types of curatives available are also presented.

Key-words: Wound healing.; defensive and curative mechanisms.

\section{I - INTRODUÇÃO: O PROCESSO DE CICATRIZAÇÃO}

A cicatrização de feridas consiste em uma perfeita e coordenada cascata de eventos celulares e moleculares que interagem para que ocorra a repavimentação e a reconstituição do tecido. ${ }^{1}$ Tal evento é um processo dinâmico que envolve fenômenos bioquímicos e fisiológicos que se comportem de forma harmoniosa a fim de garantir a restauração tissular.

Como desencadeante da cicatrização, ocorre a perda tecidual, a partir da qual o fisiologismo volta-se completamente para o reparo de um evento danoso ao organismo.

A perda tecidual pode atingir a derme completa ou incompletamente, ou mesmo atingir todo o órgão, chegan-

\section{I - INTRODUCTION: THE CICATRIZATION PROCESS}

The cicatrization of wounds consists of a perfect and coordinated chain of cellular and molecular events that interact so that the restructuring and reconstitution of the tissue can occur. ${ }^{1}$ This event is a dynamic process that involves biochemical and physiologic phenomena that behave in a harmonious way in order to guarantee the restoration of tissue.

Cicatrization is triggered by a loss of tissue, starting from which the physiology is directed efficiently to the repair of an event harmful to the organism.

The tissular loss can completely or incompletely involve the dermis, or even penetrate the organ, reaching

Recebido em 24.06.2003. / Received in June, $24^{h}$ of 2003.

Aprovado pelo Conselho Editorial e aceito para publicação em 24.06.2003. / Approved by the Editorial Council and accepted for publication in June, $24^{\text {th }}$ of 2003.

* Trabalho realizado no Serviço de Dermatologia do Hospital Universitário de Taubaté, na disciplina de Dermatologia do Departamento de Medicina da Universidade de Taubaté - Unitau, em São Paulo / Work done at the Dermatology Service of the Teaching Hospital of Taubate, Dermatology course, Department of Medicine, University of Taubate (Unitau), Sao Paulo

${ }^{l}$ Professor assistente responsável pela disciplina de Dermatologia do Departamento de Medicina da Universidade de Taubaté, em São Paulo; chefe do Serviço de Dermatologia do Hospital Universitário de Taubaté - Fust. / Assistant Professor, Dermatology Discipline of the Medicine Department of Universidade de Taubate, Sao Paulo; Head of the Dermatology Service, Taubate University Hospital - Fust.

${ }^{2}$ Especialista em Dermatologia pela SBD e AMB; preceptor do Serviço de Dermatologia do Hospital Universitário de Taubaté - Fust. / Specialist in Dermatology, Brazilian Society of Dermatology and Brazilian Medical Association; tutor, Dermatology Service of the Taubate University Hospital - Fust

${ }^{3}$ Enfermeira formada pela Universidade de São Paulo; especialista em Enfermagem em Dermatologia pela Sociedade Brasileira de Enfermagem em Dermatologia - Sobende; supervisora do Projeto Profae - Fundap / Ministério da Saúde. / Nurse graduated from University of Sao Paulo; Specialist in Dermatologic Care, Brazilian Dermatology Nurses Association - Sobende;

Supervisor, Profae-Fundap Project / Ministry of Health. 
do ao tecido celular subcutâneo. É daí que vem a definição do tipo de ferida.

Ferida de espessura parcial (derme incompleta): ocorre após muitos procedimentos dermatológicos como a dermoabrasão, o resurfacing por laser ou peelings químicos; pode também ser causada por traumatismos. A reparação faz-se pela reepitelização dos anexos epiteliais ou epitélio derivado da pele adjacente não acometida. Como resultado final tem-se uma cicatriz praticamente imperceptível.

Já as feridas de espessura total (derme completa ou estendida ao tecido celular subcutâneo) necessitam da formação de um novo tecido, o tecido de granulação; a epitelização, base da cicatrização nas feridas de espessura parcial, acontece apenas nas margens da ferida. Nesse caso, a cicatriz é totalmente perceptível e, muitas vezes, pronunciada. $^{2}$

A cicatrização também depende de vários fatores, locais e gerais, como: localização anatômica, tipo da pele, raça, técnica cirúrgica utilizada.

A cicatrização em uma mesma espécie varia se a ferida ocorre no feto, no recém-nascido ou no indivíduo adulto. ${ }^{3}$

\section{Classificação dos Processos Biológicos da Cicatrização}

Diferentes classificações didáticas são utilizadas para facilitar o entendimento de um processo totalmente dinâmico e com fases tão interdependentes como a cicatrização.

Existem autores que consideram três estágios no processo de cicatrização: inicialmente um estágio inflamatório, seguido por um de proliferação e finalizando com o reparo em um estágio de remodelação. ${ }^{4}$ Outros autores classificam de uma forma mais completa dividindo o processo em cinco fases principais:

$$
\begin{aligned}
& 1 \text { - coagulação; } \\
& 2 \text { - inflamação; } \\
& 3 \text { - proliferação; } \\
& 4 \text { - contração da ferida; } \\
& 5 \text { - remodelação. }
\end{aligned}
$$

Em um determinado período de tempo as fases coincidem e acontecem simultaneamente, permitindo assim o sucesso da cicatrização (Gráfico 1).

\section{Coagulação}

O início é imediato após o surgimento da ferida. Essa fase depende da atividade plaquetária e da cascata de coagulação. ${ }^{6}$

Ocorre uma complexa liberação de produtos. Substâncias vasoativas, proteínas adesivas, fatores de crescimento e proteases são liberadas e ditam o desencadeamento de outras fases. ${ }^{7}$

A formação do coágulo serve não apenas para coaptar as bordas das feridas, mas também para cruzar a the subcutaneous cellular tissue. It is according to this degree of penetration that the type of wound is defined.

A wound of partial thickness (incomplete dermis): occurs as a result of many dermatological procedures such as dermal abrasion, laser resurfacing or chemical peelings; it can also be caused by traumas. The repair is made by the reepithelization of the epithelial annexes or of the epithelium, derived from the adjacent unaffected skin. The end result is a practically imperceptible scar.

On the other hand, wounds of total thickness (completely penetrating the dermis or extending into the subcutaneous cellular tissue) require the formation of new tissue, granulation tissue. Epithelialization, which is the basis of cicatrization in wounds of partial thickness, only occurs in the margins of the wound. In this case, the scar remains clearly perceptible and often pronounced. ${ }^{2}$

Cicatrization also depends on several local and general factors such as: anatomical location, type of skin, race and surgical technique utilized.

Cicatrization of a wound within a given species varies widely depending on whether it occurs in the fetus, in the newborn or in the adult. ${ }^{3}$

\section{Classification of the Biological Processes of Cicatrization}

Various didactic classifications are used to facilitate the understanding of cicatrization with its highly dynamic process and its phases that are so interdependent.

Some authors propose that there are three stages in the cicatrization process: initially an inflammatory stage, followed by one of proliferation and concluding with the repair in a remodeling stage. ${ }^{4}$ Other authors make a more complete classification by dividing the process into five main phases:

$$
\begin{aligned}
& 1 \text { - coagulation; } \\
& 2 \text { - inflammation; } \\
& 3 \text { - proliferation; } \\
& 4 \text { - contraction of the wound; } \\
& 5 \text { - remodeling. }
\end{aligned}
$$

At certain periods of time the phases coincide and occur simultaneously, thereby enabling a successful cicatrization (Graph 1).

\section{Coagulation}

The first phase begins immediately after the appearance of the wound. This phase depends on the activity of the platelets and of the coagulation process. ${ }^{6}$

A complex liberation of products occurs. Vasoactive substances, adhesive proteins, growth factors and proteases are released and these dictate the triggering of the subsequent phases.

The formation of the clot serves not only for the coaptation of the borders of the wounds, but also forms a 


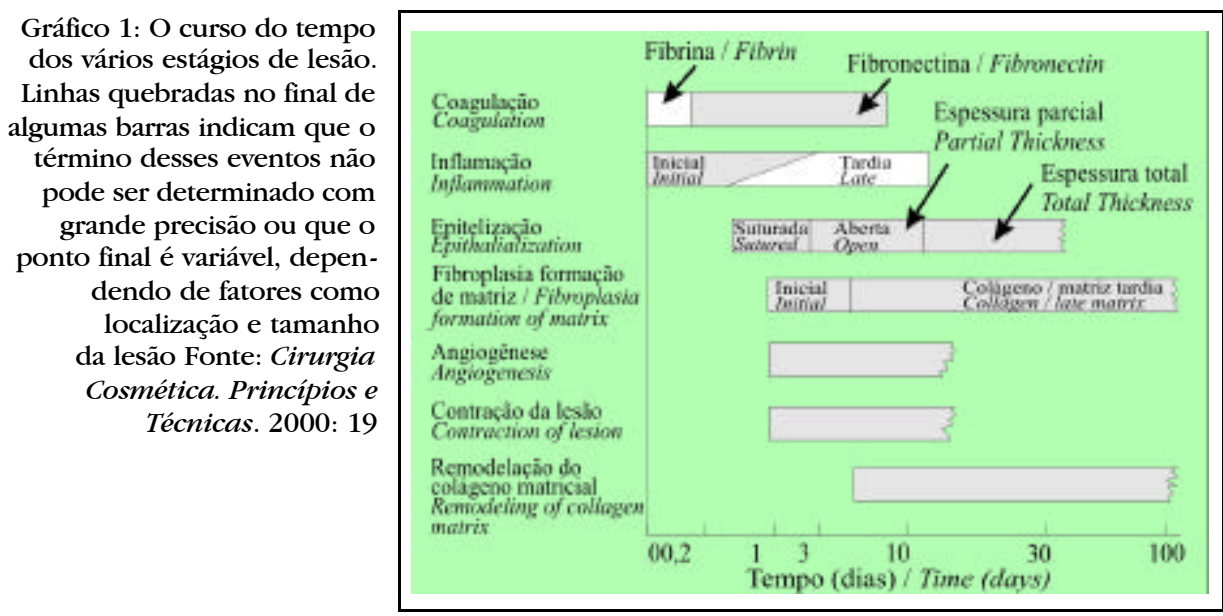

Graph 1: The course of the time of the various stages of lesions. Broken lines at the end of some bars indicate that the end of those events cannot be defined with great precision or that the final point is variable, depending on such factors as the location and size of the lesion. Source: Cirurgia Cosmética. Princípios e Técnicas [Cosmetic surgery. Principles and Techniques] 2000: 19

fibronectina, oferecendo uma matriz provisória, em que os fibroblastos, células endoteliais e queratinócitos possam ingressar na ferida. ${ }^{8,9}$

\section{Inflamação}

Intimamente ligada à fase anterior, a inflamação depende, além de inúmeros mediadores químicos, das células inflamatórias, como os leucócitos polimorfonucleares (PMN), macrófagos e linfócitos.

Os PMN chegam no momento da injúria tissular e ficam por período que varia de três a cinco dias; são eles os responsáveis pela fagocitose das bactérias.

O macrófago é a célula inflamatória mais importante dessa fase. ${ }^{10}$ Permanece do terceiro ao décimo dia. Fagocita bactérias, desbrida corpos estranhos e direciona o desenvolvimento de tecido de granulação. O uso de laser de baixa energia em pele de ratos favorece a cicatrização. Alta atividade fagocitária dos macrófagos é observada após trauma. ${ }^{11}$

Os linfócitos aparecem na ferida em aproximadamente uma semana. Seu papel não é bem definido, porém sabe-se que, com suas linfocinas, tem importante influência sobre os macrófagos.

Além das células inflamatórias e dos mediadores químicos, a fase inflamatória conta com o importante papel da fibronectina. ${ }^{12}$ Sintetizada por uma variedade de células como fibroblastos, queratinócitos e células endoteliais, ela adere, simultaneamente à fibrina, ao colágeno e a outros tipos de células, funcionando assim como cola para consolidar o coágulo de fibrina, as células e os componentes de matriz. ${ }^{13}$ Além de formar essa base para a matriz extracelular, tem propriedades quimiotáticas e promove a psonização e fagocitose de corpos estranhos e bactérias.

\section{Proliferação}

Dividida em três subfases, a proliferação é responsável pelo "fechamento" da lesão propriamente dita.

A primeira das fases da proliferação é a reepitelização. Faz-se a migração de queratinócitos não danificados das bordas da ferida e dos anexos epiteliais, quando a feri- cover of fibronectin, which offers a temporary matrix through which fibroblasts, endothelial cells and keratinocytes can enter the wound. ${ }^{8,9}$

\section{Inflammation}

Intimately linked to the previous phase, inflammation depends, in addition to countless chemical mediators, on inflammatory cells such as the polymorphonuclear (PMN) leukocytes, macrophages and lymphocytes.

$P M N$ arrive at the moment of the tissular offense and are present for period that varies from three to five days; they are responsible for the phagocytosis of the bacteria.

The macrophage is the most important inflammatory cell of this phase. ${ }^{10}$ It remains from the third to the tenth day. It phagocytizes bacteria, removes foreign bodies and directs the development of granulated tissue. A high phagocytic activity of the macrophages is observed after a trauma. ${ }^{11}$ The use of low energy of laser on the skin of mice aids in cicatrization.

Lymphocytes appear in the wound within approximately one week. Their role is not well defined, however it is known that by means of their lymphokines they have an important influence on the macrophages.

Besides the inflammatory cells and chemical mediators, fibronectin plays an important role in the inflammatory phase. ${ }^{12}$ Synthesized by a variety of cells such as fibroblasts, keratinocytes and endothelial cells, fibronectin adheres simultaneously to fibrin, to collagen and to other types of cells, functioning as a glue to consolidate the fibrin clot, the cells and other components of the matrix..$^{13}$ In addition to forming this base for the extracellular matrix, it has chemotactic properties and promotes the opsonization and phagocytosis of foreign bodies and bacteria.

\section{Proliferation}

Divided into three subphases, proliferation is responsible for the "closing" of the lesion.

The first of the subphases of proliferation is reepithelization. A migration takes place of undamaged keratinocytes from the borders of the wound and from the 
da é de espessura parcial, e apenas das margens nas de espessura total. Fatores de crescimento são os prováveis responsáveis pelos aumentos das mitoses e hiperplasia do epitélio. ${ }^{14}$

Acontecem estudos em várias partes do mundo. Utilização de colágeno e citoquinas são promessas para uma cicatrização mais rápida e eficaz. ${ }^{15}$

Sabe-se que o plano de movimento dos queratinócitos migrantes é determinado também pelo conteúdo de água no leito da ferida.

Feridas superficiais abertas e ressecadas reepitelizam mais lentamente do que as ocluídas. ${ }^{16,17}$

A segunda fase da proliferação inclui a fibroplasia e formação da matriz, que é extremamente importante na formação do tecido de granulação (coleção de elementos celulares, incluindo fibroblastos, células inflamatórias e componentes neovasculares e da matriz, como a fibronectina, as glicosaminoglicanas e o colágeno). A formação do tecido de granulação depende do fibroblasto, célula crítica na formação da matriz. Longe de ser apenas produtor de colágeno, o fibroblasto produz elastina, fibronectina, glicosaminoglicana e proteases, estas responsáveis pelo desbridamento e remodelamento fisiológico. ${ }^{18}$

A última fase da proliferação é a angiogênese, essencial para o suprimento de oxigênio e nutrientes para a cicatrização.

Inicialmente as células endoteliais migram para a área ferida, a seguir ocorre proliferação das células endoteliais, acesso para as células responsáveis pelas próximas fases.

\section{Contração da Ferida}

É o movimento centrípeto das bordas da ferida (espessura total). As feridas de espessura parcial não contam com essa fase. Uma ferida de espessura total tem contração mesmo quando há enxertos, que diminuem em $20 \%$ o tamanho da ferida. ${ }^{19}$ Em cicatrizes por segunda intenção a contração pode reduzir $62 \%$ da área de superfície do defeito cutâneo. ${ }^{20}$

\section{Remodelação}

Essa é a última das fases; ocorre no colágeno e na matriz; dura meses e é responsável pelo aumento da força de tensão e pela diminuição do tamanho da cicatriz e do eritema. Reformulações dos colágenos, melhoria nos componentes das fibras colágenas, reabsorção de água são eventos que permitem uma conexão que aumenta a força da cicatriz e diminui sua espessura. ${ }^{21}$

A neovasculatura diminui, e tardiamente a cicatriz é considerada avascular.

Uma cicatrização normal tem aproximadamente $80 \%$ da força de tensão da pele normal, não é volumosa e é plana.

Muitas variáveis tanto de ordem geral como de ordem local influenciam esse longo e complexo processo. É funda- epithelial annexes when the wound is of partial thickness, but only from the margins in a wound of total thickness. Growth factors are probably responsible for the increases in the mitoses and hyperplasia of the epithelium. ${ }^{14}$

Studies performed in various parts of the world have shown that the use of collagen and cytokines achieves a faster and more effective cicatrization. ${ }^{15}$

It is known that the water content in the bed of the wound also determines the pattern of movement of the migrating keratinocytes. Superficial wounds that are open and very dry reepithelize more slowly than those that are occluded. ${ }^{16,17}$

The second subphase of proliferation includes fibroplasia and formation of the matrix, which it is extremely important in the formation of the granulation tissue (collection of cellular elements, including fibroblasts, inflammatory cells and neovascular components of the matrix, such as fibronectin, glycosaminoglycan and collagen). The formation of granulation tissue depends on the fibroblasts, which are critical cells in the formation of the matrix. Far more than producing collagen alone, the fibroblasts produce elastin, fibronectin, glycosaminoglycan and proteases, these are responsible for the removal of foreign bodies and necrotic tissue and the physiological remodeling. ${ }^{18}$

The third subphase of proliferation is angiogenesis, essential for the supply of oxygen and nutrients for the cicatrization.

Initially the endothelial cells migrate to the injured area, following which there occurs a proliferation of these cells, providing access for other cells responsible for the next phases.

\section{Contraction of the Wound}

Contraction is the centripetal movement of the borders of the wound (total thickness). Wounds of partial thickness do not include this phase. A wound of total thickness contracts even when there is a graft, which may decrease by $20 \%$ the size of the wound. ${ }^{19}$ In healing by second intention, the contraction can reduce the surface area of the cutaneous defect by as much as $62 \%{ }^{20}$

\section{Remodeling}

Remodeling is the last of the phases; it occurs in the collagen and in the matrix. It may last for months and is responsible for the increased tension forces and for the decrease in erythema and the size of the scar. Reformulations of the collagens, improvement in the components of the collagen fibers, and reabsorption of water are events that increase the strength of the scar while reducing its thickness. ${ }^{21}$

The neovascular tissue decreases until finally the scar is considered to be avascular. A normal cicatrization has approximately $80 \%$ of the tensional strength of normal skin, is not voluminous and presents a flat surface.

Many variables both generalized and local influence this long and complex process. It is fundamentally essential 
mental uma completa e minuciosa anamnese, para avaliação de todos os fatores que podem interferir na cicatrização.

Dos fatores gerais, interferem a idade, o estado nutricional do paciente, a existência de doenças de base, como diabetes, alterações cardiocirculatórias e de coagulação, aterosclerose, disfunção renal, quadros infecciosos sistêmicos e uso de drogas sistêmicas.

Dos fatores locais, interferem a técnica cirúrgica, formação de hematomas, infecção, reação de corpo estranho, uso de drogas tópicas, ressecamento durante a cicatrização. Esses fatores devem ser de conhecimento do cirurgião dermatológico e merecem atenção especial. Nas cirurgias dermatológicas, que na maioria das vezes são eletivas, três são os fatores que devem ser destacados:

1- Técnica cirúrgica: respeitando unidades cosméticas e linhas de força; manuseio delicado evitando pinçamento das bordas; uso excessivo e, muitas vezes, desnecessário de eletrocautério; material apropriado e de boa qualidade; suturas subcutâneas para diminuição do espaço morto. Quanto à sutura da pele: promover uma aproximação natural das bordas, sem demasiado aperto, evitando isquemia, necrose e infecção da cicatriz.

2- Uso de drogas sistêmicas e principalmente tópicas. Drogas sistêmicas: especial cuidado com pacientes em uso de anticoagulantes, antiagregantes plaquetários, corticosteróides, antineoplásicos, isotretinoína. ${ }^{22,23}$ Além dos fármacos, a nicotina deve ser considerada e melhores resultados são conseguidos com a abstinência do cigarro durante 10 dias, pelo menos, antes da cirurgia e três semanas após. ${ }^{24}$

Drogas tópicas, como o uso desnecessário de associações de antibióticos, corticóides e antifúngicos: vários agentes tópicos atrapalham a migração epidérmica, se comparada ao não-tratamento: acetonido de triancinolona $0,1 \%$ diminui $34 \%$ a taxa relativa de cura; nitrofurazona diminui $30 \%$. Já o peróxido de benzoíla e coberturas com permeabilidade seletiva melhoram em $14 \%$, a sulfadiazina de prata e pomada neosporina ,em $28 \% .^{25}$

3- Ressecamento das feridas. Popularmente há a crença de que "ferida seca cura mais rápido".

Estudos demonstram que as feridas abertas formam crosta e epitelizam mais lentamente. Inúmeros curativos são então utilizados para produzir umidade local, melhorando de $35 \%$ a $45 \%$ a taxa de reepitelização de feridas profundas.

\section{II - INTERVINDO NO PROCESSO DE CICATRI- ZAÇÃO: RECURSOS, TECNOLOGIAS E PROCEDI- MENTOS}

\subsection{Evolução histórica}

As tentativas humanas de intervir no processo de cicatrização das feridas, acidentais ou provocadas intencionalmente como parte da realização de procedimentos, remontam à Antigüidade, demonstrando que desde então já se reconhecia a to make a complete and meticulous anamnesis, for evaluation of all the factors that can interfere in cicatrization.

The general factors that interfere with healing are age, the patient's nutritional state, the existence of systemic diseases such as diabetes, alterations in the cardiocirculatory system or of coagulation, arteriosclerosis, renal dysfunction, a profile of systemic infection or the use of systemic drugs.

The local factors that interfere are the kind of surgical technique being utilized, the formation of hematomas, infection, reaction to a foreign body, use of topical drugs, drying during cicatrization. The dermatological surgeon being aware of any of these factors knows that they deserve special attention. In dermatological surgeries, which are usually elective, three factors should be emphasized:

1-Surgical technique: should respect cosmetic units and lines of strength; handle the skin gently avoiding clamping the edges; avoid the excessive and many times unnecessary use of electrocauterization; use appropriate materials of good quality; sutures should be subcutaneous to decrease the amount of dead space. As for the suture of the skin: promote a natural articulation of the edges, not overly tight, thus avoiding ischemia, necrosis and infection of the scar.

2- Use of systemic and particularly topical drugs. Systemic drugs: special care should be taken with patients using anticoagulants, antiaggregation or antiplatelet agents, corticosteroids, antineoplastics, and isotretinoin. ${ }^{22,23}$ Besides the pharmaceuticals, nicotine should also be considered since better results are experienced when there is an abstinence of cigarette smoking for at least 10 days before the surgery and three weeks after. ${ }^{24}$

Topical drugs, such as the unnecessary use of associations of antibiotics, corticoids and antifungal agents: several of these topical agents disturb epidermal migration. If compared to non-treatment: $0.1 \%$ triamcinolone acetonide reduces by $34 \%$ the relative rate of cure; nitrofurazone reduces this by 30\%. While benzoyl peroxide and salves with selective permeability offer an improvement of $14 \%$ and silver sulfadiazine and neosporine ointment $28 \%{ }^{25}$

3- Drying of the wounds. Popularly in Brazil there is a belief that "dry wounds heal faster."

However, studies have demonstrated that dry open wounds form a scab and epithelize more slowly. Therefore many curatives have been devised to produce local humidity, thereby improving by 35\% to $45 \%$ the rate of reepithelization of deep wounds.

\section{II - INTERVENING IN THE PROCESS OF CICATRI- ZATION: RESOURCES, TECHNOLOGIES AND PROCEDURES}

\subsection{Historical Background}

Since antiquity human attempts at intervening in the process of cicatrization of wounds have been related or recorded. Regardless of whether wounds came about accidentally or provoked intentionally as part of the perform- 
importância de protegê-las de forma a evitar que se complicassem e repercutissem em danos locais ou gerais para o paciente.

Embora tenham sido verificados grandes avanços na compreensão dos processos e fenômenos envolvidos nas diversas fases da reparação tissular e simultaneamente muito se tenha investido em pesquisa e desenvolvimento de recursos e tecnologias com o objetivo de favorecer esses processos, a incidência e prevalência de úlceras crônicas é ainda extremamente alta , repercutindo em elevados custos financeiros e profundas conseqüências sociais sobre os portadores, os quais com frequiência desenvolvem sequielas que podem levar à perda de membros e de suas funções, com conseqüente afastamento do trabalho e de suas atividades normais, como refere Moryson. ${ }^{26}$

Embora não haja dados precisos no Brasil, alguns trabalhos demonstram que o impacto psíquico, social e econômico da cronificação de lesões, em especial as úlceras crônicas dos pés e pernas, representa a segunda causa de afastamento do trabalho no Brasil. ${ }^{27}$

Isso demonstra que, embora se acredite que tudo já foi descoberto e pesquisado no campo da cicatrização e dos curativos e que existem recursos e tecnologias em excesso no mercado, muito há que se pesquisar nesse campo não só para aperfeiçoar tais recursos, como para torná-los acessíveis a maior número de pessoas, mediante o desenvolvimento de tecnologias mais simples e baratas, igualmente eficientes, que se aproveitem de matérias-primas encontradas nessas regiões menos desenvolvidas, pois um dos desafios para o profissional é o elevado custo de tais recursos, em sua maioria importados e cuja tecnologia é patenteada por empresas multinacionais. ${ }^{27}$

Os registros mais antigos, citados por Zimmerman e $V_{\text {Veith }}{ }^{28}$ falam sobre manuscritos egípcios que datam de 3000-2500 a.C, e neles são mencionados curativos à base de mel, graxa, fios de linho e diversos tipos de excrementos, que faziam parte dos princípios da farmacopéia egípcia.

Hipócrates, que lançou as bases da medicina científica, recomendava que as feridas fossem mantidas limpas e secas, e preconizava sua limpeza com água morna, vinho e vinagre. Foi ele também quem criou os conceitos de cicatrização por primeira ou segunda intenção, como refere Trevelyn, citado por Dealey. ${ }^{29}$

A partir do século XIX, durante a Guerra da Criméia, foram criados vários tipos de curativos, à base de fibras de linho, que, sendo reutilizadas várias vezes, se tornavam gradativamente mais macias, mas eram pouco absorventes.

Por volta de 1860, Gamgee descobre o processo de remoção do óleo da lã de algodão, tornando-o absorvível, e cria o chumaço de algodão envolto em gaze, ainda hoje utilizado.

Entre o final de 1840 e a Segunda Guerra Mundial, o foco para o tratamento de feridas e cicatrização foi a utilização de anti-sépticos e agentes tópicos com ação antimicrobiana e a proteção com coberturas secas, como conseqüência às descobertas de Pasteur sobre a "Teoria dos Germes". Nessa fase, como referem Sinclair e Ryan, ${ }^{30}$ dá-se ance of medical procedures, the importance of participating in the healing process was already recognized. Over the ages methods were developed for protecting the patient from local and general complications and repercussions.

Great progress has been made in the understanding of the processes and phenomena involved in the various phases of tissue repair. In recent years there has been considerable investment in research and development of resources and technologies with the objective of favoring these processes. Even so, the incidence and prevalence of chronic epidermal ulcers is still extremely high, creating high financial costs for the sufferers as well as profound social consequences. These can cause patients to lose members and their functions, with consequent loss of work and of their normal activities, as described by Moryson. ${ }^{26}$

Although there are no precise data here in Brazil, some works have shown that the psychic, social and economic impact of the chronicity of lesions, especially the chronic ulcers of the feet and legs, represents the number two cause of labor loss in Brazil. ${ }^{27}$

This shows that, although some may believe that everything has already been discovered and researched in the field of cicatrization and that remedies, resources and technologies exist in excess in the market, the fact is that there is much to research in this field. Not only will it be necessary to improve existing resources, but also to find ways to make them accessible to a greater number of people. This will require the development of simpler and less expensive technologies that are at least as efficient and take advantage of raw materials found in the less developed regions. Therefore one of the challenges for the professional is how to reduce the high cost of such resources, the majority of which are imported and whose technology is patented by multinational companies. ${ }^{27}$

The oldest medical reports, mentioned by Zimmerman and Veith ${ }^{28}$ speak of Egyptian manuscripts that date from 30002500 B.C. In these curatives are mentioned that are based on honey, grease, linen threads and several types of excrement. These were part of the beginnings of Egyptian pharmacopoeia.

Hypocrites, who established the basics of modern scientific medicine, recommended that wounds should be maintained clean and dry, and extolled cleansing them with lukewarm water, wine and vinegar. It was also he who created the concepts of healing by first or second intention, as referred to by Trevelyn and cited by Dealey. ${ }^{29}$

Starting in the nineteenth century, during the Crimean War, several types of curatives were created based on the use of linen fibers, that, being reused several times became gradually softer, although they were not very absorbent.

About 1860, Gamgee discovered a process for the removal of the oil from cotton fibers, rendering them absorbent. He used them to create a wad of cotton wrapped up in gauze, much like that which is still in use today.

Between the end of the 1840s and the Second World War, the focus for the treatment of wounds and cicatrization was the use of antiseptic and topical agents with antimicrobial action and protection with dry coverings. This new 
o período áureo de utilização de anti-sépticos como o líquido de Dakin, Eusol, derivados de iodo, mercúrio e alumínio.

Até o final da Segunda Guerra Mundial os recursos utilizados para a proteção das lesões baseavam-se na crença de que o ambiente seco proporcionava melhores condições de cicatrização, sendo largamente desenvolvidos e utilizados agentes tópicos que provocavam o dessecamento do leito da ferida, e as coberturas consistiam basicamente de gaze seca, fixada com espessa camada de fitas adesivas.

Em 1945, Bloom relata pela primeira vez a utilização de um filme transparente, permeável ao vapor, em 55 pacientes com queimaduras, e descreve seu efeito benéfico no processo de cicatrização. Posteriormente, em 1950, Schilling apresenta novos estudos com a utilização desse tipo de filme, envolto em moldura adesiva de polivinil, que veio trazer as bases para o desenvolvimento dos futuros recursos, como referido por Field. ${ }^{31}$

Embora já se aceitasse o pressuposto de que a criação de um ambiente úmido na ferida trazia efeitos extremamente benéficos para o processo cicatricial, bem como reduzia a dor, devido à proteção das terminações nervosas contra o dessecamento, até início da década de 1960 esses recursos ainda não estavam sendo desenvolvidos pela indústria. Só a partir de 1962, quando Winter e Roove ${ }^{16}$ demonstraram que a taxa de epitelização era $50 \%$ mais rápida em um ambiente úmido e que a formação de crostas era minimizada, houve grande interesse pelo desenvolvimento de pesquisas, produção e comercialização desse tipo de recurso, ocorrendo uma verdadeira "revolução no conceito de curativos"

Nos Estados Unidos e Europa, registra-se uma avalancha de novos recursos a partir de 1970, gerando entre os profissionais grande confusão quanto a sua adequada indicação e utilização; em contrapartida, não se tinham evidências sobre os reais benefícios de cada um desses recursos, nem estudos controlados sobre custo/benefício de cada um deles.

Com essa preocupação, diversos órgãos e agências passaram a coordenar estudos que pudessem estabelecer critérios para a avaliação adequada das feridas e, concomitantemente, indicar parâmetros que direcionassem a adequada seleção desses recursos, de acordo com tais critérios, como refere Goldsmith. ${ }^{32}$

Esses critérios, parâmetros e escalas de avaliação têm sido exaustivamente estudados, e, embora ainda exista muita controvérsia entre os diversos grupos, de forma geral todos eles buscam reunir as melhores evidências sobre as diversas tecnologias, os materiais, recursos e procedimentos, disponibilizando e divulgando o máximo de informações e referências, cujo acesso pode ser facilmente obtido pelos sites dessas agências na internet (www.npuap.org e www.ahcpr.org).

A partir de 1980 passam a ser realizados estudos em larga escala, nos Estados Unidos e em vários países da approach came as a consequence of the discoveries of Pasteur on the "The Theory of Germs". That period is referred to by Sinclair and Ryan, ${ }^{30}$ as the golden age because antiseptic liquids such as Dakin and Eusol, derived from iodine, mercury and aluminum began to be used.

Until the end of Second World War the resources used for the protection of lesions were based on the belief that a dry ambient provided better conditions for cicatrization. Topical agents were broadly developed and utilized that promoted the desiccation of the bed of the wound, and the dressings consisted basically of dry gauze, fastened with a thick layer of adhesive tapes.

In 1945, Bloom reports for the first time of the use of a transparent film, permeable to vapor, on 55 burn patients. He describes the beneficial effect in the cicatrization process. Later, in 1950, Schilling presented new experiments in the use of that type of film framed in an adhesive polyvinyl, this came to be the basis for the future development of new resources, as referred to by Field. ${ }^{31}$

Although it has been accepted for some time that the creation of a humid atmosphere in the wound brought extremely beneficial effects for the healing process, as well as reducing pain. This benefit was due to the protection of the nerve endings against the effects of drying. Yet although this premise had been accepted, the necessary resources and procedures, even by the beginning of the decade of the 1960s, were still not being developed by the medical industry. In 1962 Winter and Roove ${ }^{16}$ demonstrated that the rate of epithelialization was $50 \%$ faster in a humid atmosphere and that the formation of scabs was minimized. Only after that date was there great interest in the development of researches, production and commercialization of resources of this type. There occurred a true "revolution in the concept of curatives".

In the United States and Europe, starting in 1970 there began a virtual avalanche of new resources. This generated among professionals a great confusion as to the appropriate indication and use of the new materials. At the same time, experimental evidence was not available on the comparative real benefits of each of these resources, nor were there controlled cost-benefit studies for each of them.

Consequently, several organs and agencies began to coordinate studies to establish criteria for the appropriate evaluation of wounds and, concomitantly, to indicate parameters to direct the appropriate selection of the available resources in accord with the criteria, as referred to by Goldsmith. ${ }^{32}$

These criteria, parameters and evaluation scales have been studied exhaustively. Although there still exists controversy among the various groups, in general they all seek to gather the best evidence on the various technologies, materials, resources and procedures. They each publish and make available a large amount of information and references. These can be obtained easily by accessing the sites of these agencies on the Internet (www.npuap.org and www.ahcpr.org). 
Europa, visando desenvolver instrumentos mais adequados para a avaliação de feridas e princípios para a reformulação de protocolos e revisão de procedimentos e de técnicas utilizadas para a realização de curativos..$^{33}$

Em 1982 as coberturas à base de hidrocolóides são lançadas nos Estados Unidos e Europa, passando a ser largamente utilizadas em feridas de espessura parcial. Tais coberturas só foram disponibilizadas no mercado brasileiro a partir da década de 1990, e seu custo elevado foi uma barreira inicial para sua difusão. Também no início dos anos 90 são lançados os hidropolímeros, que, além de manter o meio úmido, agregavam a propriedade de promover a evaporação do exsudato, favorecendo a granulação e diminuindo a maceração de tecidos neoformados.

Nesse período o número de publicações sobre o assunto cresceu vertiginosamente nesses países; no Brasil, só a partir da década de 1990, com a chegada dos primeiros curativos chamados "modernos", é que o assunto passou a ser alvo de estudos e pesquisas, em especial nas universi dades. ${ }^{32}$

Grande parte das publicações sobre recursos, tecnologias e procedimentos para o tratamento de feridas é fragmentada, consistindo em relatos isolados sobre um ou outro tipo de agente tópico ou cobertura em alguns tipos de ferida, mas tais estudos são freqüentemente descontinuados, e os resultados não trazem evidências precisas quanto a custo/benefício de cada um deles, como refere Dantas. ${ }^{33}$

O impacto social e econômico da cronificação de feridas e suas conseqüências, devido à infecção local ou sistêmica, tem sido alvo de grande preocupação por parte dos profissionais, fazendo com que, na década de 1990 a utilização de anti-sépticos e dos mais variados tipos de agentes antimicrobianos se tornasse uma panacéia com repercussões extremamente danosas. Com o estabelecimento de estudos controlados do efeito desses diversos agentes sobre os tecidos, pôde-se constatar que a maioria provocava mais danos do que benefícios, e sua utilização tem-se tornado cada vez mais restrita, como refere Ribeiro. ${ }^{34}$

Ayello, ${ }^{35}$ ao analisar a situação atual em termos de tratamento de feridas crônicas nos Estados Unidos, especialmente devido à grande preocupação das autoridades e seguradoras norte-americanas com relação aos elevados e crescentes custos desses pacientes, chama atenção dos profissionais para vários mitos e crenças que, de forma sutil, se incorporam ao cotidiano e, sem que se perceba, passam a ser vistos como verdades.

Entre eles, alguns devem ser destacados, pois comumente são utilizados como argumentos para manutenção de condutas inadequadas por parte dos profissionais.

"Curativos especiais, industrializados são melhores do que curativos simples."

"O cuidado de feridas é um procedimento estéril."

"O cliente/paciente ou familiar não precisa de orientação."
From 1980 on, large-scale studies have been accomplished in the United States and in several countries of Europe, seeking to develop more appropriate instruments for the evaluation of wounds, principles for the reformulation of protocols and revision of procedures and of techniques used for the realization of curatives. ${ }^{33}$

In 1982 dressings with a hydrocolloidal base were launched in the United States and Europe. These came to be used mainly in wounds of partial thickness. Such dressings were only made available in the Brazilian market as of 1990s, but their high cost initially became a barrier to their diffusion. Also in the beginning of the nineties the hydropolymers became available. These had the advantage that, besides maintaining humidity of the wound, they promoted the evaporation of the exudate, favoring granulation and a reduction in the maceration of newly formed tissues.

During that period the number of publications on the subject increased dramatically in these countries. In Brazil, starting only in the decade of the 1990s with the arrival of the first curatives considered to be "modern", the subject began to be the object of studies and research, especially in the universities. ${ }^{32}$

A large part of the publications on resources, technologies and procedures for the treatment of wounds is fragmented, consisting of isolated reports on one or another type of topical agent or dressing for some specific wound types. Such studies are frequently discontinued, and the results do not bring necessary information as to the comparative cost-benefit of each of them, as is mentioned by Dantas. ${ }^{33}$

The social and economical impact of the chronicity of wounds and their consequences, due to local or systemic infection, has been the objective of great concern on the part of professionals. In the decade of the 1990s there was a danger that the use of antiseptics and of the most varied types of antimicrobial agents might come to be considered a panacea, which could have extremely harmful repercussions. With the establishment of controlled studies on the effects these several agents have on the tissues, it could then be verified that most of them caused more damage than benefits, and their use has been more and more restricted, as reported by Ribeiro. ${ }^{34}$

Ayello, ${ }^{35}$ on analyzing the current situation of the treatment of chronic wounds in the United States, especially in view of the major concern of the authorities and North American insurance companies in relation to the high and growing costs of those patients, called attention to several myths and beliefs. These, in a subtle way, have been incorporated into the daily practice and, without being noticed and have come to be seen as truths.

Among them, some should be underscored because they are used commonly as arguments for maintaining inadequate conduct on the part of health professionals:

"Special industrialized curatives are better than simple curatives."

"The care of wounds is a sterile procedure." 
"Os novos recursos da tecnologia substituirão o cuidado."

"Tudo já foi pesquisado e descoberto sobre tratamento de feridas."

Segundo Ayello, ${ }^{35}$ o sucesso no tratamento de feridas depende mais da competência e do conhecimento dos profissionais envolvidos, de sua capacidade de avaliar e selecionar adequadamente técnicas e recursos, do que da disponibilidade de recursos e tecnologias sofisticadas. Para uma intervenção efetiva no processo cicatricial, com o objetivo de favorecê-lo, isso implica a necessidade de estabelecer metas realistas, que considerem os diversos fatores, como o diagnóstico preciso do tipo de lesão e seu estágio cicatricial, e critérios clínicos e técni$\cos$ (Figura 2.1).

\subsection{Componentes do processo de seleção de recursos para otimizar a cicatrização}

Pergunta freqüente entre os profissionais é: qual o melhor curativo para tal tipo de ferida?

Essa resposta não existe de forma absoluta, pois, feridas diferentes, em diferentes tipos de pacientes, requerem diferentes formas de tratamento. Como refere Dealey, ${ }^{27}$ não se pode fazer esse tipo de comparação de forma absoluta, pois o tratamento de lesões com o objetivo de favorecer sua cicatrização não se restringe ao estabelecimento de rotinas para troca de curativos ou ao estabelecimento de protocolos sobre o uso de produtos.

As grandes mudanças ocorridas nas últimas décadas nos conceitos referentes à cicatrização têm mobilizado as indústrias a desenvolver e colocar no mercado produtos cada dia mais específicos que sejam eficazes e adequados a cada tipo de ferida em termos de custo/benefício.

Segundo Cuzzell, ${ }^{36}$ existem hoje no mercado aproximadamente 2.500 itens que se destinam ao tratamento de feridas agudas e crônicas, desde a mais simples cobertura, soluções para higienização e anti-sepsia até os mais complexos tipos de curativos, chamados "curativos inteligentes" ou "bioativos", que interferem de forma ativa nas diversas fases do processo cicatricial, dos vários tipos de feridas. Se por um lado tal diversidade de opções é um fator altamente positivo, por outro, pode tornar extremamente desafiadora a decisão.

Figura 2.1: Prescrição do tratamento baseado em estudos clínicos controlados Fonte: Gogia, 2003: 32
"The client/patient or relative does not need orientation."

"The new technological resources can substitute care."

"Everything has already been researched and discovered regarding treatment of wounds."

According to Ayello, ${ }^{35}$ success in the treatment of wounds depends more on the competence and knowledge of the involved professionals, on their capacity to evaluate and to select techniques and resources appropriately, than on the availability of resources and sophisticated technologies. An effective intervention in the process of cicatrization with the objective of aiding it, implies the need to establish realistic goals that consider the various factors, starting with the precise diagnosis of the lesion type and its phase of cicatrization, as well as clinical and technical criteria (Figure 2.1).

\subsection{Components in the process of selection of resources to optimize cicatrization}

A frequent question among health workers is: which is the best curative for such a type of wound?

There is no absolute answer, since different wounds, in different types of patients, require different forms of treatment. As stated by Dealey, ${ }^{27}$ you can not make this type of comparison in an absolute way, because the treatment of lesions with the objective of favoring their cicatrization is not limited to the establishment of routines for changing curatives or to the establishment of protocols for the use of products.

The major changes seen in the last decades to the concepts regarding cicatrization have been mobilizing the industries to develop and market products which are ever increasingly specific, effective and appropriate for each type of wound in terms of cost/benefit.

According to Cuzzell, ${ }^{36}$ today there are approximately 2,500 items on the market that are destined for the treatment of acute and chronic wounds, ranging from the simplest covering, solutions for cleansing and antisepsis to the more complex types of curatives, known as "intelligent curatives" or "bioactive", that actively interfere in the diverse phases of the cicatricial process of various types of

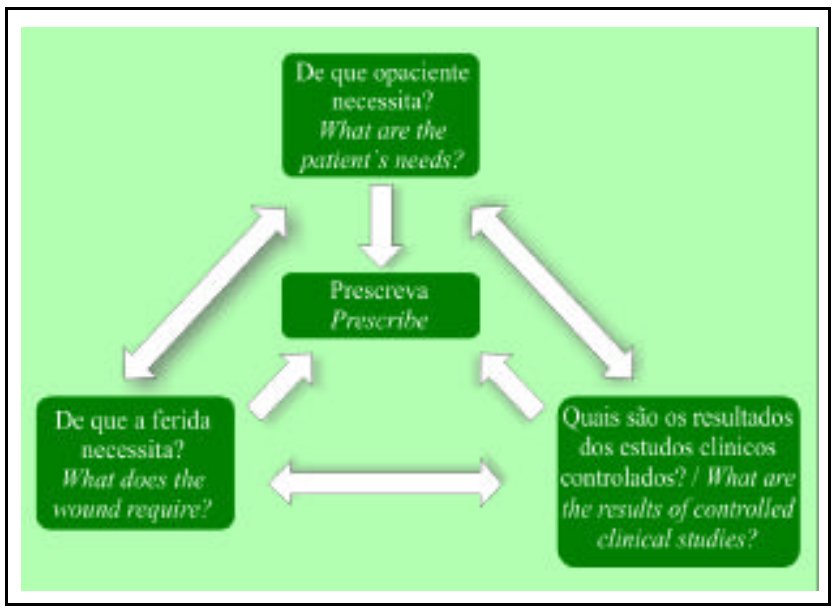
wounds. If on the one hand such a diversity of options is a highly positive factor, on the other, it can make decision process extremely challenging.

Figure 2.1: Prescription of treatment based on controlled clinical studies Source: Gogia, 2003: 32 
Para direcionar esse processo de escolha, Cuzzell ${ }^{36}$ reforça a idéia de que é fundamental uma acurada avaliação da lesão, identificando-se cuidadosamente o estágio do processo cicatricial e tomando-se a decisão a partir dessa avaliação, que, aliás, deve ser sistemática e periodicamente realizada, com critérios bem estabelecidos e protocolos de avaliação, como refere Marquez. ${ }^{37}$

Os produtos para tratamentos de feridas podem ser reunidos em dois grandes grupos: agentes tópicos e curativos.

Agentes tópicos são aqueles aplicados diretamente sobre o leito da ferida ou destinados à limpeza ou proteção da área em seu redor. Curativo, também chamado por alguns autores de cobertura, é o recurso que cobre uma ferida, com o objetivo de favorecer o processo de cicatrização e protegê-la contra agressões externas, mantendo-a úmida e preservando a integridade de sua região periférica. ${ }^{29}$

Normalmente os curativos são divididos em primários, quando usados em contato direto com o tecido lesado, e secundários, quando colocados sobre o curativo primário. Algumas coberturas destinam-se basicamente a atuar como curativo secundário; outros, por sua vez, requerem a utilização de cobertura secundária, como será tratado a seguir.

Com a oferta crescente e diversificada desses recursos, aliada a uma estratégia publicitária intensiva junto aos profissionais, o processo de tomada de decisão pode ficar comprometido se nele prevalecerem fatores como a pressão da mídia ou apenas o custo dos produtos.

Deve-se considerar que a utilização de recursos para otimizar a cicatrização e reparação tecidual é um processo multifatorial e de caráter multidisciplinar, ${ }^{33}$ que precisa levar em conta os seguintes parâmetros, como ressalta Hill: ${ }^{38}$

- os clientes portadores de feridas, agudas ou crônicas, lesões primárias ou lesões secundárias, infectadas ou não, com suas necessidades e expectativas de um tratamento eficaz e que lhes ofereça qualidade de vida;

- os profissionais de saúde, com seu conhecimento técnico-científico e suas ferramentas para a implementação de medidas preventivas, profiláticas e curativas no tratamento das lesões, e abordagem holística do paciente;

- as indústrias, que pesquisam, desenvolvem e produzem materiais e recursos, e esperam ver seus produtos difundidos no mercado, para retorno desse investimento;

- as instituições de saúde, públicas e privadas, com seus recursos orçamentários e seus critérios para seleção de recursos. Em grande número de instituições públicas os recursos são exíguos para atender à grande demanda de clientes de baixo poder aquisitivo, que freqüentemente desenvolvem afecções mais graves. Por outro lado, as instituições privadas e as seguradoras estabelecem critérios cada vez mais rígidos para autorizar a utilização de recursos e tecnologias mais sofisticadas, devido à necessidade de controle de custos.
To guide the selection process, Cuzzell ${ }^{36}$ underscores the idea that an accurate evaluation of the lesion is fundamental, carefully identifying the stage of the cicatricial process and basing the decision on this evaluation, which, in fact, should be systematically and periodically performed, with well established criteria and evaluation protocols, as described by Marquez. ${ }^{37}$

The products for treatment of wounds can be divided into two major groups: topical agents and curatives.

Topical agents are those applied directly onto the bed of the wound or destined for the cleaning or protection of the surrounding area. Curative, also called covering by some authors, it is the resource to cover a wound, with the objective of favoring the cicatrization process and to protect it against external aggressions, maintaining the wound humid and preserving the integrity of its surrounding area. $^{29}$

The curatives are usually classified as primary, when used in direct contact with the damaged tissue and secondary, when applied on the primary curative. Some coverings are destined basically to act as secondary curative; while others require the use of a secondary covering, as discussed below.

With the growing and diversified supply of these resources, allied to an intensive advertising strategy aimed at health professionals, the decision making process could be compromised if allowed to be over influenced by media pressure or merely the cost of the products.

It should be considered that the use of resources to optimize the cicatrization and tissular repairing is a multifactorial process with a multidisciplinary character, ${ }^{33}$ which needs to take into account the following parameters, as emphasized by Hill: ${ }^{38}$

- the clients presenting wounds, acute or chronic, primary lesions or secondary lesions, infected or uninfect$e d$, with their needs and expectations of an effective treatment that offers quality of life;

- health professionals, with their technical-scientific knowledge and tools for the implementation of preventive measures, prophylactics and curatives for the treatment of lesions, together with a holistic approach to the patients;

- the industries, that research, develop and produce materials and resources, and hope to see their products in the market to generate a return on their investment;

- the health institutions, whether public or private, with their criteria and budget for selection and purchase of resources. In a great number of public institutions the resources are all too few to attend the great demand of clients with low purchasing power, who frequently develop the more serious diseases. On the other hand, the private institutions and health insurance companies are establishing more and more rigid criteria to authorize the use of more sophisticated resources and technologies, due to the need to control costs. 
Ao selecionar os recursos que serão utilizados, é fundamental uma análise cuidadosa de cada um desses componentes, pois o sucesso no processo de tomada de decisão para a escolha dos recursos deve ter como objetivo harmonizar esses diversos elementos, tendo-se como base princípios permanentemente revisados sobre a fisiopatologia do processo de reparação tecidual e do tratamento de feridas, como refere Rijiswijk. ${ }^{39}$

\subsection{Fatores que interferem na escolha dos recursos}

\subsubsection{Necessidades do cliente}

A avaliação geral do cliente é um dos fatores mais importantes do processo de tratamento de feridas, como refere Sheridan, ${ }^{40}$ pois toda e qualquer proposta de intervenção deve levar em conta não só a lesão a ser tratada, mas o portador da mesma, com suas características e necessidades. Nessa avaliação devem ser consideradas algumas ações:

a) diagnosticar os fatores intrínsecos (decorrentes das condições gerais do paciente) e extrínsecos, que possam interferir na evolução do processo cicatricial;

b) identificar as expectativas do cliente e família, suas possibilidades econômico-financeiras de manutenção. Avaliar, quanto ao custo/benefício, a relação entre medidas preventivas mais simples e tratamentos mais complexos;

c) avaliar a disponibilidade do paciente e da família para realizar o curativo e a facilidade de utilização do recurso selecionado;

d) avaliar os fatores que possam interferir na aderência ao tratamento proposto e em sua continuidade;

e) buscar a independência, estabelecendo um planejamento que leve o paciente ao autocuidado. Inúmeros trabalhos têm demonstrado que portadores de feridas crônicas se tornam dependentes de cuidadores familiares ou profis sionais, devido a falhas no processo de educação para o autocuidado. Outros autores têm salientado que as lesões da pele, especialmente as crônicas, provocam alterações de auto-imagem, e os indivíduos desenvolvem um processo de negação e resistência em relação a tais lesões, evitando olhá-las, tocá-las e delas cuidar;

f) promover a qualidade de vida além da cicatrização e do fechamento das lesões, pois o processo de tomada de decisão quanto aos procedimentos, recursos e tecnologias que serão utilizados deve buscar a preservação das potencialidades e bem-estar das pessoas que os utilizam, e para isso é fundamental que haja participação, envolvimento e respeito às opiniões do paciente e da família.

\subsubsection{Avaliação da Ferida}

Bryant, ${ }^{40}$ entre outros autores, e diversas agências reguladoras norte-americanas, como a AHCPR, ${ }^{41}$ destacam que a avaliação é uma parte fundamental do processo de tratamento das lesões da pele, pois só o diagnóstico preciso do tipo e estágio da lesão vai permitir a correta tomada de
When selecting the resources that they will be used, a careful analysis of each one of these components is fundamental, because success in the decision making process for the choice of resources should have as an objective the harmonization of these diverse elements. Furthermore this should be based on continuously revised principles of the physiopathology of the tissular repair process and treatment of wounds, as described by Rijiswijk. ${ }^{39}$

\subsection{Factors influencing the choice of resources}

\subsubsection{The client's needs}

The general evaluation of the patient is one of the most important factors in the process of treating wounds, as affirmed by Sheridan, ${ }^{40}$ since each and every intervention proposal should take into account not only the lesion to be treated, but the patient's individual characteristics and needs. In this evaluation one should consider the following actions:

a) to diagnose the intrinsic factors (due to the patient's general condition) and extrinsic factors, which could interfere in the course of the healing process;

b) to identify the expectations of the patient and family, as well as their economic-financial situation. To evaluate, the cost/benefit relationship between the simpler preventive measures and more complex treatments;

c) to evaluate the potential of the patient and family to apply curatives and the ease of use of the selected resource;

d) to evaluate factors that could interfere in the adherence to the proposed treatment and in its continuity;

e) to seek independence, establishing a plan that leads the patient to self-care. Countless works have demonstrated those with chronic wounds become dependent on family or professional health care, due to failures in the process of education for self-care. Other authors have pointed out that skin lesions, and especially the chronic type, cause problems in the self image and such individuals may develop a denial process and resistance in relation to the lesions, avoiding looking at them, touching them and even treating them;

f) to promote quality of life besides closing and cicatrization of the lesions, since the decision making process for the procedures, resources and technologies that will be used should have the goal of preserving the potential and well-being of the people that use them, and for this it is fundamental that there is participation, involvement and respect for the opinions of the patients and their family.

\subsubsection{Evaluation of the wound}

Bryant, ${ }^{40}$ and other authors as well as several North American regulatory agencies, such as the AHCPR, ${ }^{41}$ highlight that the evaluation is a fundamental part of the process of treating skin lesions, because only a precise diagnosis of the type and stage of the lesion enables a correct decision 
decisão sobre as medidas a serem implementadas e os recursos que serão utilizados. Um roteiro sistemático de avaliação deve incluir:

a) história e exame subjetivo do cliente;

b) dados objetivos do cliente: condições gerais, exames laboratoriais, doenças associadas;

c) avaliação do risco, com base nas condições gerais do cliente e do local da lesão;

d) avaliação e classificação adequada da lesão: localização, tempo de evolução, medida do tamanho, diâmetro, profundidade, vitalidade do leito e dos tecidos circunvizinhos, presença de secreção e necrose, coloração do leito da ferida, sensibilidade cutânea, comprometimentos;

e) diagnóstico adequado do tipo de ferida, suas necessidades e conseqüente planejamento de ações.

Podem ser utilizados diversos sistemas, alguns mais indicados para a avaliação de feridas agudas, outros especialmente desenvolvidos para a avaliação de feridas crônicas. Vários instrumentos têm sido criados para facilitar e direcionar o processo de avaliação, e alguns já estão validados no Brasil.

Nos Estados Unidos têm sido desenvolvidos alguns sistemas que auxiliam os profissionais nesse processo de avaliação e facilitam a tomada de decisão sobre os procedimentos e recursos a serem utilizados. Entre eles, vários trabalhos têm relatado e difundido a utilização do sistema Red/Yellow/Black - RYB, ${ }^{42}$ proposto por Cuzzel, ${ }^{43}$ para classificação de feridas que cicatrizam por segunda intenção. Segundo tal sistema, as feridas são classificadas de acordo com a coloração que, afirma a autora, freqüentemente reflete o balanço entre tecidos novos e tecidos necrosados. $\mathrm{O}$ sistema RYB assim classifica as feridas:

- as vermelhas incluem sítios doadores de enxertos, feridas pós-desbridamento, feridas crônicas em cicatrização, em que predomina o tecido de granulação e novo epitélio. Nesse tipo de ferida, o objetivo do tratamento é favorecer o ambiente úmido, proteger os tecidos neoformados e prevenir a infecção;

- as amarelas normalmente apresentam exsudato fibroso e seus tecidos são moles, desvitalizados; elas podem estar colonizadas, o que favorece a instalação de infecção. Nesse tipo de ferida o objetivo é identificar adequadamente a presença ou não de infecção e, neste último caso, promover o desbridamento dos tecidos desvitalizados e estancar a infecção, preferencialmente por meio de terapia sistêmica;

- as pretas apresentam necrose tecidual, com desnaturação e aumento de fibras colágenas, e conseqüente formação de escara espessa, cuja coloração pode variar entre castanho, marrom e preto. Nesse tipo de ferida, devido à presença do tecido necrótico, o objetivo é remover o tecido necrosado com a máxima brevidade, por meio do desbridamento.

É evidente que a coloração não constitui um parâmetro preciso de avaliação da ferida e não deve ser o único, pois normalmente as feridas apresentam combinações dessas diversas colorações, de acordo com a profundidade da lesão, das terapias usadas e das condições locais e gerais. regarding the measures to be implemented and the resources to be used. A systematic evaluation protocol should include:

a) history and subjective exam of client;

b) objective data of the client: general condition, laboratory exams and associated diseases;

c) evaluation of the risk, based on the client's general condition and location of the lesion;

d) evaluation and appropriate classification of the lesion: location, duration, measurement of the size, diameter, depth, vitality of the bed and adjacent tissues, presence of secretion and necrosis, coloration of the wound bed, cutaneous sensitivity and impairment;

e) appropriate diagnosis of the wound type, its necessities and consequent planning of action.

Several systems can be used, some more suitable for the evaluation of acute wounds and others especially developed for the evaluation of chronic wounds. Several instruments have been created to facilitate and to address the evaluation process, and some of these have already been validated in Brazil.

In the United States, several systems have been developed that aid the professionals in this evaluation process and facilitate the decision making process regarding the procedures and resources to be used. Among these, several works have described and recommended the use of the Red/Yellow/Black - RYB system, ${ }^{42}$ as proposed by Cuzzel, ${ }^{43}$ for classification of wound healing by second intention. According to this system, the wounds are classified in terms of their coloration which, the author affirms, frequently reflects the balance between new and necrotic tissues. The $R Y B$ system classifies wounds as follows.

- red wounds include the sites of graft donations, post dermabrasion wounds and chronic wounds in cicatrization with a prevalence of granulation tissue and new epithelium. In this wound type, the objective of the treatment is to favor a humid environment, to protect the neoformation of tissues and to prevent infection;

- yellow wounds usually present a fibrous exudate and their tissues are soft, devitalized and can be colonized, which favors the installation of infection. In this type of wound the objective is to adequately determine the presence or absence of infection and, in the latter case, to promote the removal of the devitalized tissues and to stop infection, preferentially through systemic therapy;

- black wounds present tissular necrosis, with denaturation and increase in the collagen fibers, and consequent formation of thick eschar, whose coloration can vary between chestnut, brown and black. In this wound type, the objective is to clear away the necrotic tissue with the utmost brevity by removing foreign bodies and necrotic tissue.

It is evident that the coloration alone does not constitute a precise parameter for evaluation of wounds, since they usually present combinations of the diverse coloration, in accordance with the depth of the lesion, the therapies used and the local and general conditions. 
Outro sistema útil para avaliação e estabelecimento de condutas e objetivos, assim como para acompanhamento da evolução do tratamento, é a escala Push Tool, proposta pela NPUAP $^{44}$ que, partindo dos parâmetros acima, permite a categorização da lesão e auxilia no direcionamento das medidas de intervenção em cada uma das fases do processo cicatricial, permite avaliar eficácia de medidas e recursos utilizados e a evolução do processo cicatricial.

\subsubsection{Oferta de produtos}

Devido à diversidade de tipos e marcas de produtos, é importante que sejam considerados alguns aspectos quando da análise para sua escolha, aquisição e indicação:

1) documentação técnico-científica do produto fornecida pelos fabricantes; estudos clínicos realizados e metodologia de utilização para avaliação e validação desses recursos;

2) comprovação de resultados, ou seja, evidências clínicas, mediante estudos padronizados, veiculados em publicações científicas reconhecidas;

3) origem dos produtos e das matérias-primas utilizadas, atestando seriedade, experiência, compromisso e registro nos órgãos de fiscalização;

4) custo/benefício - avaliação do custo inicial e de manutenção, e dos investimentos por meio da elaboração de planilhas comparativas entre os diversos recursos, que considere não apenas seu preço inicial, mas se baseie em estudos controlados dos diversos elementos envolvidos;

5) disponibilidade do produto e facilidade de acesso;

6) atendimento ao cliente por parte do fabricante (serviço de atendimento ao consumidor) para orientação e substituição em caso de iatrogenias ou descontinuidade de produção;

7) atendimento à instituição e aos pesquisadores;

8) qualidade de vida - iatrogenias, autocuidado, independência, educação, motivação;

9) pesquisa e avaliação, incluindo ensaios clínicos, testes, grupo piloto;

10) auditoria e serviço de atendimento aos consumidores;

11) controle de qualidade constante;

12) treinamento e reciclagem dos usuários, clientes e profissionais;

13) facilidade de utilização pelos clientes e profis sionais;

14) biodegradabilidade/preocupação com meio ambiente;

\subsubsection{Recursos da instituição}

1) Formação de grupos multiprofissionais nas instituições para definição de procedimentos e seleção de recursos.

2) Participação efetiva de especialistas nos proces sos de tomada de decisão para compra de materiais.

3) Atualização constante de protocolos e estudos de
Another useful system for evaluation and establishment of management and objectives, as well as for following up the course of the treatment, is the Push Tool scale, proposed by NPUAP ${ }^{44}$ which, based on the above parameters, enables a categorization of the lesion and aids in the planning of the intervention measures for each of the phases in the cicatrization process, while allowing an evaluation of the effectiveness of the measures and resources used and the course of the wound healing process.

\subsubsection{Supply of products}

Due to the diversity of the types and brands of products, it is important that some aspects are considered during the analysis of their choice, acquisition and indication:

1) technical-scientific documentation of the product supplied by the manufacturers; clinical studies undertaken and methodology for the use evaluation and validation of these resources;

2) proof of results, or in other words clinical evidence by standardized studies, published in recognized scientific journals;

3) origin of the products and raw materials used, attesting confidence, experience, commitment and registration in the competent authorities;

4) cost/benefit - evaluation of the initial cost and maintenance, and the investments by means of the elaboration of comparative spreadsheets for the various resources, which do not merely consider the initial price, but are based on controlled studies of each of the elements involved;

5) availability of the product and ease of access;

6) customer service provided by the manufacturer (consumer advisory service) for orientation and substitution in case of iatrogenic response or discontinued production;

7) service for institutions and researchers;

8) life quality - iatrogenic responses, self-care, independence, education, motivation;

9) research and evaluation, including clinical trials, tests, pilot group;

10) auditing and consumer attendance service;

11) constant quality control;

12) training and courses for users, clients and professionals;

13) ease of use for customers and professionals;

14) biodegradability/concern with environment;

\subsubsection{Resources of the institution}

1) Formation of multi-disciplinary groups in the institutions for definition of procedures and selection of resources.

2) Effective participation of specialists in the decision-making processes for purchase of materials.

3) Constant updating of protocols and cost/benefit 


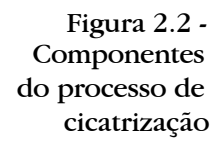

custo/benefício.

4) Embasamento técnico-científico seguro.

5) Avaliação constante.

6) Qualidade sob todos os ângulos.

7) Custo/benefício.

8) Qualidade de vida.

9) Protocolos atualizados e acessíveis.

10) Pesquisa constante e atualização profissional reciclagem de conhecimentos $\mathrm{X}$ modismos.

11) Decisões em equipe multiprofissional - estudos de casos - publicação de resultados com base em evidências.

12) Metodologia científica rigorosa.

(ver figura 2.2)

\subsubsection{Elementos para proposição de um plano de tratamento que favoreça o processo de cicatriza- ção com enfoque multidisciplinar}

13) Cuidados de ordem geral: alimentação, nutrição, higiene, deambulação ou mobilização.

14) Cuidados com a ferida: avaliação a cada troca de curativo, por meio de instrumentos e critérios adequados já referidos, e documentação, utilizando escalas de avaliação, também já referidas.

15) Estabelecimento de procedimentos e técnicas, e sua permanente reavaliação e revisão pela equipe multidisciplinar: a equipe deve discutir as diversas etapas do processo de tratamento de lesões, assim como selecionar e indicar o conjunto de recursos que serão utilizados, tanto nos aspectos preventivos como nos de recuperação.

Esse conjunto de recursos e tecnologias deve ser decidido em equipe, por meio do estabelecimento de protocolos básicos, que devem incluir:

- procedimentos para higienização da ferida, com a utilização de técnicas e recursos atualizados constantemente, com base em evidências da literatura;

- procedimentos e recursos para remoção de tecido necrótico desvitalizado, de acordo com o tipo de ferida;

- recursos para proteção da ferida e da área periférica, e prevenção de infecção;

- coberturas adequadas ao tipo de ferida, selecionadas conforme parâmetros relativos a: localização da ferida (saliências ósseas, local anatomico, região de dobras); área (comprimento x largura) e profundidade da lesão; características e quantidade de exsudato; existência
Figure 2. 2

Components of

the cicatriza-

tion process

studies.

4) Safe technical -scientific foundation.

5) Constant evaluation.

6) Quality under all

aspects.

7) Cost/benefit.

8) Quality of life.

9) Updated and accessible protocols.

10) Constant research and professional updating recycling of knowledge $X$ trends.

11) Decisions in multi-disciplinary team - case studies - publication of results based on evidence.

12) Rigorous scientific methodology.

(see figure 2.2)

\subsubsection{Elements for proposition of a treatment plan that favors the cicatrization process with a multidisciplinary focus}

13) General care: nutrition, hygiene, deambulation or mobilization.

14) Care of wound: evaluation at each change of curative, through instruments and criteria that are appropriate as described above and documentation, using evaluation scales, also referred to above.

15) Establishment of procedures and techniques, and their permanent revaluation and revision by the multidisciplinary team: the team should discuss the various stages in the process of treating lesions, as well as to select and indicate the set of resources that will be used, regarding aspects of prevention and recovery.

This group of resources and technologies should be resolved by the team, through the establishment of basic protocols, that should include:

- procedures for cleanliness of the wound, via constantly updated techniques and resources, based on evidence in the literature;

- procedures and resources for removal of devitalized necrotic tissue, in accordance with the type of wound;

- resources for protection of the wound and peripheral area, and prevention of infection;

- appropriate coverings for the wound type, selected according to parameters relative to: location of the wound (bone protuberances, anatomic site, area of folds); area (length $x$ width) and depth of the lesion; characteristics and amount of exudate; existence of tunnels or cavities, vitality of the tissues in the bed of the wound and conditions of the 
de túneis ou cavidades, vitalidade dos tecidos do leito da ferida e condições das bordas, presença de edema, odor, coloração do leito e área próxima.

16) Diagnóstico preciso do tipo de ferida e estágio do processo cicatricial, e estabelecimento de metas e objetivos em função de cada estágio.

17) Treinamento e reciclagem contínua das equipes.

18) Acompanhamento e documentação para controle e avaliação, e estabelecimento de evidências sobre a eficácia dos diversos recursos e reavaliação contínua.

\section{REFERÊNCIAS / REFERENCES}

1. Ortonne JP, Clévy JP. Physiologie de la cicatrisation cutanée. Ver Prat 1994; 44(13): 1733-4.

2. Fazio MJ, Zitelli JA, Goslen JB. Cicatrização de feridas. In: Coleman III WP, Hanke CW, Alt TH, Asken S. Cirurgia Cosmética - Princípios e Técnicas. 2.ed. Rio de Janeiro: Revinter, 2000:18-23.

3. Julía V, Albert A, Morales L, Miró D, Bombi J, Sancho A. Características de la cicatrización de las heridas en el período fetal. Cir Pediatr 1992; 5(3): 117-21.

4. Ortonne JP, Clévy JP. Physiologie de la cicatrisation cutanée. Rev. Prat 1944; 44(13); 1735-7.

5. Fazio MJ, Zitelli JA, Goslen JB. Cicatrização de feridas. In: Coleman III WP, Hanke CW, Alt TH, Asken S. Cirurgia Cosmética - Princípios e Técnicas. 2.ed. Rio de Janeiro: Revinter, 2000:23-28.

6. Terkeltaub RA, Ginsberg MH. Platelets and response to injury. In: Clark RAF, Henson PM, editors: The molecular and cellular biology of wound repair. New York: Plenum Press, 1998.

7. Clark RAF. Cutaneous tissue repair. Basic biologic considerations. J Am Acad Dermatol 1985;13:701.

8. Clark RAF, Lanigan JM, Dellapelle P et al. Fibronectin and fibrin provide a provisional matrix for epidermal cell migration during wound reepithelization, J Invest Dermatol 1982;(79):264.

9. Grinnel F, Billinghiam RE, Burgess L. Distribution of fibronectin during wound healing in vivo. J Invest Dermatol 1981; (76): 181 .

10. Diegelmann RF, Cohen IK, Kaplan AM. The role of macrophages in wound repair: a review. Plast Reconstr Surg 1981; (68): 107.

11. Petrova MB. Morfofunktsional'nye osobennosti zazhivleniia kozhnoi rany u krys pri vozdeistvii nizkointensivnogo lazernogo izlucheniia. Morfologiia, 1992;102(6):112-21.

12. Clark RAR. Potential roles of fibronectin in cutaneous wound repair. Arch Dermatol 1998; 124:201.

13. Mosher DF, Furcht LT. Fibronectin: review of its structure and possible functions. J Invest Dermatol 1981; (77):175.

14. Christopher E. Kinetic aspects of epidermal healing. In: Maibach H, Rovee D. eds. Epidermal wound healing. St Louis: Mosby., 1972

15. Gentilhomme E, Neveux Y, Lebeau J, Desmouliere A, Bergier J, Schmitt D, Haftek M. Modulation of a fibrotic process induced by transforming growth factor beta- 1 in dermal equivalents. Cell Biol Toxicol 1999;15(4):229-38. borders, presence of edema, odor, coloration of the bed and adjoining area.

16) Precise diagnosis of the wound type and stage in the cicatricial process, and establishment of goals and objectives in function of each stage.

17) Training and continuous recycling of the teams.

18) Follow-up and documentation for control and evaluation, and establishment of evidence regarding the effectiveness of the various resources and continuous reevaluation.

16. Winter GD. Formation of the scab and the rate of epithelization of superficial wounds in the skin of the young domestic pig. Nature 1962;(193):293.

17. Hinman CD, Maibach H. Effect of air exposure and occlusion on experimental human skin wounds. Nature 1963;(200):377.

18. Van Winkle W. The fibroblast in wound healing. Surg Ginecol Obstet 1967;(124):369.

19. Stegman SJ, Tromovitch TA, Glogau RG. Grafts. In: Basics of Dermatological Surgery. St Louis: Mosby, 1982.

20. Lawrence CM, Comaish HS, Dahl MGC. Excision of skin tumors without wound closure. Br J Dermatol 1986;(115):563.

21. Doillon CJ, Dunn MG, Bender E et al. Collagen fiber formation in repair tissue. Development of strength and toughness. Collagen Rel Res 1985;(5):481.

22. Marks JG, Cano C, Lietzel K et al. Inhibition of wound healing by topical steroids. J Dermatol Surg Oncol 1983;(9):819.

23. Rubenstein R, Roenigk Jr HH, Stegman SJ et al. Atypical keloids after dermabrasion of patients taking isotretinoin. J Am Acad Dermatol 1986;(15):280.

24. Rees TD, Liverett DM, Guy CL. The effect of cigarette smoking on skin-flap survival in the face lift patient. Plast Reconstr Surg 1984;(73):911.

25. Fazio MJ, Zitelli JA, Goslen JB. Cicatrização de feridas. In: Coleman III WP, Hanke CW, Alt TH, Asken S. Cirurgia Cosmética - Princípios e Técnicas. 2.ed. Rio de Janeiro: Revinter, 2000:28-38.

26. Moryson M. Leg Ulcers. In: Moryson M. Nursing Management of chronic wounds. Cap. 10, p.177-220. Mosby, London, 2nd edition, 1998.

27. Ereno D. Curativo de Borracha. Revista Pesquisa Fapesp, número 88, junho de 2003, disponível em http://www.fapesp.org.br/ www.revistapesquisa.fapesp.br

28. Zimmerman LM, Veith I. Great ideas in the History. Baltimore, Wilkins \& Wilkins Co. 1961.

29. Dealey C. Cuidando de Feridas: um guia para as enfermeiras. São Paulo, Atheneu Editora, $2^{a}$ edição, 2001, capítulo 3: p. 49-65, capítulo 4: p. 68-89; cap. 9: p. 200-207.

30. Sinclair RD, Ryan TJ. A great war for antiseptics. Wound Mangement, 4(1):16-18, 1993.

31. Field C, Kerstein M. Overview of wound healing in a moist environment. Am J Surgery, 167:25-65, 1994.

32. Goldsmith SP. Wound care: combining three classification sys- 
tems to select dressings. Home Health Care Mangement and Practice, 8(6):17-26, 1996

33. Dantas SRPE. Aspectos históricos do tratamento de feridas. In: Jorge SA. Abordagem Multiprofissional do tratamento de feridas, cap. 1, p. 3-6, São Paulo: Atheneu, 2003.

34. Ribeiro SMCP. Soluções anti-sépticas em curativos. In: Jorge SA. Abordagem Multiprofissional do Tratamento de Feridas, cap. 9: p. 101-109. São Paulo: Atheneu, 2003.

35. Ayello E, Franz R. Pressure ulcer prevent and treatment: competency-based nursing curricula. Dermatology Nursing, 15(1):4465, February, 2003.

36. Cuzzel J, Krasner D. Curativos. In: Gogia P. Feridas - tratamento e cicatrização. Rio de Janeiro: Livraria Editora Revinter Ltda. cap 9, p. 103-114, 2003.

37. Marquez RR. Avaliação da ferida. In: Gogia P. Feridas - tratamento e cicatrização, Rio de Janeiro: Livraria e Editora Revinter Ltda, cap. 2, p. 11-23; 2003.

38. Hill MJ. Dermatologic Nursing Essentials: a core curriculum. New Jersey, DNA/ Pitman Editor, 1998. Cap. 18, p. 295-317.

39. Rijswijk L V. Princípios gerais do tratamento de feridas. In: Gogia, P. Feridas - tratamento e cicatrização, Rio de Janeiro: Livraria Revinter Ltda. cap. 3, p. 23-37, 2003.
40. Bryant RA. Acute and chronic wounds. Saint Louis, Mosby, 2nd edition, 2000.

41. Agency fo Health Care Policy and Research (AHCPR) Clinical practice guidelines: pressure ulcer treatment: quick reference guide for clinicians. Dermatology Nursing, 7(2): 87-101.

42. Wound Healing: Translating theory into clinical practice. Dermatology Nursing, 14 ( 4 ): 257-261, august 2002

43. Cuzzel JZ. The new RYB color code. American Journal of Nursing, 88 (10): 1342-1346, 1988.

44. National Pressure Ulcer Advisory Panel . PUSH Tool information and registration form. (2002) In: NPUAP Website http://www.npuap.org.

ENDEREÇO PARA CORRESPONDÊNCIA: / MAILING ADDRESS:

Samuel Henrique Mandelbaum

Av. 9 de julbo, 520 - cjs. 3 e 4

São José dos Campos SP 12243-001

Tel/Fax: (12) 3921-5455 / 3942-8549

E-mail:dr_samuel@directnet.com.br 
1) Assinale a alternativa falsa:

a) A cicatrização é evento complexo e dinâmico.

b) A cicatrização final depende da perda tecidual inicial.

c) Muitos eventos dermatológicos contam com a cica trização em derme incompleta.

d) As fases da cicatrização são bem determinadas e individualizadas.

e) A cicatrização depende de vários fatores como: localização anatômica, tipo da pele, raça, e técnica cirúrgica utilizada.

2) Qual das alternativas abaixo não corresponde à cicatrização em derme completa?

a) A cicatriz é perceptível.

b) Muitas vezes a cicatriz é pronunciada.

c) A reparação se faz basicamente pela reepitelização.

d) Necessita de formação de um novo tecido.

e) Pode se estender até tecido celular subcutâneo.

3) Em relação à coagulação, podemos afirmar:

a) $\mathrm{O}$ início é imediato após o surgimento da ferida.

b) Independe de outras atividades como a plaquetária e cascata de coagulação.

c) Inúmeros produtos como substâncias vasoativas são liberadas, e são importantes apenas para esta fase.

d) É a única fase individual, sendo bem particularizada das subseqüentes.

e) O coágulo é imprescindível para coaptar as bordas das feridas, e imediatamente fagocitado por não ter mais nenhum papel relevante nesta fase.

4) As células mais importantes da fase inflamatória são:
a) Leucócitos Polimorfonucleares
b) Eosinófilos
c) Linfócitos
d) Plasmócitos
e) Macrófagos

5) As primeiras células a chegar à ferida são:
a) Macrófagos
b) Plasmócitos
c) Linfócitos
d) Eosinófilos
e) Leucócitos Polimorfonucleares

6) Importante na fase inflamatória, sobre a fibronectina podemos afirmar:
a) Sintetizada por várias células.
b) Funciona como cola para consolidar o colágeno de fibrina, às células e os componentes da matriz.
c) É munida de propriedades quimiotáticas.
d) Promove opsonização e fagocitose de corpos estra nhos e bactérias.
e) Todas as alternativas estão corretas.

7) Para a formação do tecido de granulação, é extremamente importante:
a) Coagulação.
b) Fibroplasia e formação da matriz.
c) Reepitelização.
d) Atividade plasmocitária.
e) Ação quimiotática dos leucócitos.

8) Em relação a contração da ferida, é errado afirmar:
a) Movimento centrípeto das bordas.
b) Ocorre em todas as feridas de espessura parcial.
c) Ocorre mesmo quando há enxertos.
d) Pode passar de $50 \%$ em cicatrizes por segunda intenção.
e) Facilita por diminuição da área o reparo do defeito cutâneo.

9) A remodelação ocorre:
a) Rapidamente e logo após a coagulação.
b) Aumentando a quantidade de água, para melhor efeito final da cicatriz.
c) No colágeno e na matriz.
d) Para aumentar a espessura da cicatriz e diminuir a sua força de tensão.
e) Visando aumentar a vascularização da cicatriz.

10) Existem muitas variáveis que podem modificar o efeito final da cicatriz:
a) Uso de drogas sistêmicas.
b) Uso de drogas tópicas
c) Técnica cirúrgica respeitando unidades estéticas, evitando o pinçamento, e promovendo uma aproxi mação natural das bordas.
d) Material cirúrgico utilizado, em feridas provocadas.
e) Todas acima são variáveis importantes e devem ser consideradas em cirurgia dermatológica.

11. O desenvolvimento de recursos e tecnologias para otimizar o processo cicatricial foi especialmente acelerado:

a) logo após a Segunda Guerra Mundial, com o adven

to dos antibióticos tópicos

b) na década de 60 , com o surgimento dos anti-sépticos e descoberta do papel dos fatores de crescimento na cicatrização

c) a partir de 1970 , com a descoberta dos curativos modernos, que minimizaram o fator humano na rea lização dos procedimentos

d) a partir de 1960, com as pesquisas sobre os efeitos do meio úmido no processo de cicatrização e) a partir da década de 90, com o desenvolvimento da engenharia de tecidos e do Projeto Genoma 
12. Dentre os fatores abaixo, identifique aqueles que retardam ou impedem a cicatrização de lesões abertas, de forma mais imperativa:

a) idade e utilização de antibióticos sistêmicos

b) pressão contínua sobre o local e manutenção da lesão em meio seco

c) doenças pré existentes e uso de anti-sépticos

d) estado nutricional e uso de curativos não industria lizados

e) presença de infecção e técnica de limpeza utilizada

13. De acordo com o sistema RYB as feridas são classificadas:

a) pelo grau de lesão tissular, em 4 estágios diferentes

b) pelo tipo e volume de exsudato, em 3 grupos: alta mente ex-sudativas, moderamente exsudativas e não exsudativas

c) pela profundidade, podendo ser superficiais ou pro fundas,

d) pela coloração do leito da ferida

e) pelo tamanho da lesão quanto ao seu diâmetro

14. Considerando-se que a cicatrização é um processo multifatorial, segundo Hill, que parâmetros devem ser avaliados quando se busca otimizar este processo:

a) tipos de curativos, tipos de feridas, tipo de pacientes

e profissionais

b) pacientes, produtos, recursos financeiros, tipos de feridas

c) profissionais,clientes,indústrias , instituições

d) recursos humanos,tipos de feridas, pacientes, recursos materiais

e) tipos de feridas, recursos institucionais,pacientes, tipos de curativos

15. Dos elementos abaixo, assinale aqueles que têm influência direta sobre a decisão do tipo de cobertura a ser utilizada em uma lesão:
a) causa, tempo de evolução e localização da lesão
b) tamanho, localização e tipo de exsudato
c) profundidade, causa e coloração da lesão
d) localização, tempo de evolução, presença de odor
e) coloração, presença de infecção, causa da lesão

16. A limpeza das feridas abertas é um assunto controverso, mas alguns consensos recomendam que:

a) para a limpeza de feridas crônicas deve-se utilizar anti-sépticos e a técnica deve ser estéril

b) em todos os tipos de feridas o ideal é que se utilize água e sabão neutro

c) as feridas abertas devem ser limpas através da fricção de gaze embebida em soluções anti-sépticas recomendadas pelos órgãos de controle de infecções, diluí das em solução salina d) a limpeza da maioria das feridas abertas deve ser feita com o uso de soluções isotônicas através de irri gação sob pressão controlada

e) todas as alternativas estão corretas

17. A prescrição de tratamento baseado em estudos clínicos controlados deve levar em conta:

a) necessidades do paciente, necessidades da ferida, resultados dos estudos clínicos

b) estudos clínicos controlados, evolução do paciente , evolução da ferida

c) evolução da ferida, evolução clínica do paciente, resultados obtidos

d) avaliação do paciente, prescrição do curativo, evolução da ferida

e) avaliação da ferida, tipo de curativo, evolução

18. Das alternativas abaixo, assinale a afirmação correta :

a) $\mathrm{O}$ cuidado de feridas é um procedimento estéril

b) Os curativos industrializados substituiram os cura

tivos artesanais pois são mais seguros

c) Os recursos hoje disponíveis para auxiliar na cica trização são suficientes e não são necessários novos processos e pesquisas

d) A competência dos profissionais influe de maneira mais efetiva no processo de cicatrização do que os recursos existentes

e) Com o advento dos curativos modernos a cicatriza ção de feridas deixou de ser um problema

19. Os primeiros registros sobre a utilização de recursos para favorecer o processo de cicatrização são atribuídos a:

a) aos gregos, a partir dos trabalhos de Hipócrates

b) aos fenícios, com o uso de anti-sépticos

c) aos romanos, com a utilização de mel sobre as feridas

d) aos egípcios, com o uso de excrementos de animais

e) aos babilônios, com o uso de plantas medicinais

20. Os recursos disponíveis no mercado para o tratamento de feridas podem ser classificados em dois grandes grupos:
a) anti-sépticos e curativos
b) coberturas primárias e coberturas secundárias
c) agentes tópicos e coberturas
d) curativos oclusivos e não oclusivos
e) curativos úmidos e curativos secos

\section{GABARITO}

Vitamina C

2003; 78(3): 265-274

$\begin{array}{llll}01-\mathrm{d} & 05-\mathrm{a} & 09-\mathrm{c} & 13-\mathrm{d} \\ 02-\mathrm{c} & 06-\mathrm{b} & 10-\mathrm{c} & 14-\mathrm{c} \\ 03-\mathrm{c} & 07-\mathrm{d} & 11-\mathrm{a} & 15-\mathrm{b} \\ 04-\mathrm{a} & 08-\mathrm{b} & 12-\mathrm{c} & \end{array}$

